\title{
Initiating Financial Technology (Fintech) as an Innovation of Communication Technology on Credit Cooperatives in Indonesia
}

\author{
Sugiyanto \\ Indonesia Institute of Cooperative Management (IKOPIN \\ Wawan Lulus Setiawan
}

Indonesia Institute of Cooperative Management (IKOPIN

\begin{abstract}
The purpose of this study is to describe the possibility to initiate Finansial Technology (Fintech) as an innovation of communication technology on the credit cooperatives in Indonesia. This study is based on the phenomenon of tremendous growth of credit / financial business by using FinTech in Indonesia . Fintech so far has grew uncontrolablely among illegal financial institutions and gave unexpected impact on lower income people in Indonesia. On the other hand, the credit cooperatives as legal financial institutions which could facilitate lower income people for financial services lag behind. This study used quantitative-desciptive method, and resulted in some findings: (1) Cooperatives can become the fintech P2PL Platform model, as an alternative business model by changing conventional savings and loan businesses into the P2PL platform. The model could also be seen as a solution to prevent moral hazard due to miss-used of this technology among illegal credit instituions, (2) Fintech as an innovation is recognized feasible to apply. It has good relative advantage due to giving more efficiency and effectiveness on mana gement, it has good trialability because it may be easily experimented with on a limited basis, and has good observability because the result is visible to others, it has less complexity since it is easy to learn and apply. This study has implications for policies that fintech flatform model could be developed for credit cooperatives in Indonesia both in rural and urban areas..
\end{abstract}

Keywords: Financial-technology, communication-technology, credit cooperative, crowdfund-P2PL

\section{Introduction}

Financial Technology (fintech) is an innovation in the field of financial services that 
is growing rapidly including in Indonesia. Financial Services Outhority (OJK) data for 2020 illustrated that the domicile of fintech companies is mostly in Java Island (155 units) and the rest are domiciled outside of Java Island with the ownership status of 113 companies representing national ownership and 51 foreign ownership companies. ${ }^{1}$

The following Table I is data on loan distribution for the past 3 years through fintech in Indonesia

Table I: the Cooperatives as the Subject of the Study

\begin{tabular}{|l|l|l|l|l|}
\hline Description & unit & 2017 & 2018 & $2019 *)$ \\
\hline Java Island: & & & & \\
\hline Loan distribution & (billion Rp) & $2.185,63$ & $19.617,46$ & $63.861,88$ \\
\hline Progress & $(\%)$ & & 797,57 & 225,54 \\
\hline $\begin{array}{l}\text { Outside of Java } \\
\text { Island }\end{array}$ & & & & \\
\hline Loan distribution & (billion Rp) & 378,32 & $3.048,61$ & $10.682,82$ \\
\hline Progress & (\%) & & 705,83 & 250,42 \\
\hline National & & & & \\
\hline Loan distribution & (billion Rp) & $2.563,95$ & $22.666,07$ & $74.544,70$ \\
\hline Progrress & (\%) & & 784,03 & 228,88 \\
\hline
\end{tabular}

*) Loan Accumulation Until November 2019,

Source: OJK, 2020

The data illustrates the extraordinary business development, with an increase in lending reaching $784.03 \%$ in 2018 from 2017, and 228.88\% in 2019 from 2018. This is a huge business potential that can be utilized by any parties .

Apart from the positive side of the development of fintech-based financial business in Indonesia, there is a dark side to this business, that most of these businesses are

${ }^{1}$ Kompas Daily January 4, 2020, 
illegal. 947 fintech units have been closed in 2018 and 2019 by the Financial Services Authority (OJK). There have been many complaints from the public about practices that harm consumers from this fintech business.

The above conditions, that on the one hand the development of fintech-based business is a potential business opportunity, but on the other hand this business also has the potential to be used for practices that are detrimental to consumers because of the moral hazard of its managers, which opens up thinking about fintech opportunities managed by cooperatives . The Financial Services Authority Regulation explains that legally fintech can be managed through corporation and / or cooperatives [1]. Almost all formal fintech applications are currently corporation, only a small proportion are cooperative legal entities. Even though cooperatives in Indonesia also have business experience in the financial sector (savings and loan businesses). Therefore it is very possible if the cooperative business is given the opportunity to develop a savings and loan business using fintech.

Cooperatives with values, principles and characteristics are possible to be able to conduct this business better, because of the position of members as owners and users of cooperative services (member dual identity) [2]. As users, members can function as providers of funds to lend to other members who need funds, especially Small and Medium Enterprises (SMEs) entrepreneurs who are also members of cooperatives. The orientation of a cooperative is as a service provider to its members, rather than it has a for-profit orientation, with the aim of improving the welfare of its members [3].

Based on the above background we conducted a study entitled Initiating Financial Technology (Fintech) ss An innovation of comm unication technology on credit cooperatives in Indonesia.. This study was conducted by quantitative desciptive method. The purpose of writing this paper is to formulate an alternative model for developing savings and loan (credit) cooperative using the Fintech platform based on various business constraints of fintech and of cooperative savings and loan businesses

\section{State of the Art}

\section{Conceptual Framework}

Financial Technology : Financial Technology, which later became known as fintech, developed as a new business model in the financial sector. Fintech is an innovation in the financial sector by utilizing information technology to create and popularize new financial, institutional and market instruments. Ref [4] states more specifically that fintech or financial technology is a term used to denote firms that offer modern technology in the financial sector. Thus fintech innovation is related to institutional aspects, products and processes. This innovation has changed people's behavior in financial transactions, obtaining real products and other services by not having to 
leave other activities or even leaving home.

Fintech is developing very rapidly not only in Indonesia but also throughout the world in the last decade. The main factors driving the development of extraordinary fintech are the emergence of new technologies that can provide mobility, ease of use (visualization of information), speed and lower cost of financial services [5].

Understanding of fintech has been conveyed by many experts, including that fintech entered the market as an activity by utilizing technology to provide financial services [8]. In addition, fintech is a service sector, which uses mobile-centered IT technology to enhance the efficiency of the financial system [9]. Fintech is also seen as an economic industry composed of companies that use technology to make financial systems more efficient [10]. Another interesting definition describes fintech as a process driven by technology in the financial industry which introduces new work methods and approaches to standard processes [12].

Studies on fintech have been carried out by many academics and professionals, including Saksonova1 and Merlino, 2017, Vlasov, 2017; Vovchenko et al., 2017; Setyawati et al., 2017 in [4]. Furthermore, [4] denoted the results of his study which describes the data that fintech is one of the fastest growing sectors of the economy. Investments in the industry have increased rapidly reaching 12.2 billion dollars in 2014, while in 2008, it was only 930 million dollars. The highest increase was observed in Europe. The total volume of investment in fintech in these regions was $\$$ 46.7 billion in 2015. In 2016 it fell to $\$ 24.3$ billion.

In Indonesia, fintech is a legal business. The legal basis for organizing fintech in Indonesia includes: Bank of Indonesia Regulation No. 18/40 / PBI / 2016 concerning Implementation of Payment Transaction Processing [6], Bank of Indonesia Circular No. 18/22 / DKSP regarding the Implementation of Digital Financial Services [7] and Bank of Indonesia Regulation No. 18/17 / PBI / 2016 concerning Electronic Money [8].

The Financial Stability Board describes fintech as a financial innovation that is technologically possible that can produce new business models, applications, processes, or products with related material effects on markets and financial institutions and the provision of financial services [9].

Fintech, Crowdfunding and P2PL: There are many definitions of crowdfunding, no single universal definition that all people could agree for crowdfunding. We prefer to adopt the definition mentioned by [5] that "Crowdfunding is a way for people to get fund or capital to be used for social activity, expand their business or create a new line of product from the crowd themselves using the online method. It also includes the reward system for the investors in the form of special privileges, giving discount prices, and others."

Ref [10] specifies that there are various forms of crowdfunding, which are classified 
as follows: (1) Phil anthropies Crowdfunding, funders donate for philanthropic purposes, especially for charities and non-profit organizations, although in practice also profit-oriented companies can participate in such initiatives . Lenders donate for reasons they believe in and might be symbolically valued, but not with material returns. The risks associated with this model are very low, because people cannot expect returns. (2) Commercial Crowdfunding, financing artistic or innovative ideas, this method for financing projects or products in the initial stages for a start-up business. (3) Royalty Crowdfunding, investors or funders receive benefits or income sharing related to investment, but without any claim on project property or capital replacement. (4) Crowd investing, this platform with operations in the form of financing for investment purposes, so it is associated with remuneration. In this category include:

a) Equity-based crowdfunding, is a direct form to finance a company, the purpose of the capital owner is to obtain a share of income (dividends),

b) Loan based crowdfunding: the owner of the fund supplies the funds for a certain period, hoping to get a return on the principal and interest. This form of crowdfunding is the most consistent operation so far,

c) Trading invoices, consisting of transfers of commercial invoices to obtain liquidity

Crowfunding models 3 and 4, are models that have been developed by investors because they are valued according to the purpose of capital ownership, which is to invest or lend to business people who have difficulty financing their business or projects.

The existence of fintech is currently very supportive of crowdfunding activities. Based on the interrelationships between the two, the Financial Stability Board makes groups of fintech businesses, into: (1) Peer-to-peer Lending (P2PL) and Crowdfunding, (2) Market Aggregators, (3) Investment and Risk Management, and (4) Payment, Clearing, and settlement) [9]. Fintech's Crowdfunding and P2PL categories function to bring investors together with capital seekers

Bank of Indonesia divides fintech into 4 categories, one of which is Crowdfunding and P2PL categories. In this category, fintech serves to bring together investors (capital owners) with those who need funds (borrowers), Crowdfunding can also be used to raise funds for social purposes, such as victims of natural disasters, funding works and so on online. Meanwhile, P2PL is a service to help capital for SMEs so that they can borrow funds even though they do not have a bank account.

Fintech as a Computer-mediated Communication innovation in the Business Field : The development of Information Technology in the world today which is supported by internet technology increasingly supports the development of communication techniques among humans that are increasingly sophisticated, effective and efficient in various fields of human life, namely computer mediated communication (CMC). 
Conceptually Computer-mediated communication is "communication that takes place between human beings via the instrumentality of computers" (Thurlow, Lengel, \& Tomic, 2004, p.83) in [11]. Financial technology (fintech) is a form of innovation in CMC in business activities.

From a communication perspective, innovation is an idea, practice, or object that is perceived as new by an individual or other unit of adoption [12]. As an innovation, fintech is currently used by the world community as described in the discussion above. This innovation is diffused from sources of innovation in developed countries throughout the world. The speed of adoption of fintech by a group of people is influenced by how people perceive fintech characteristics as an innovation as explained by [12] including 4 factors: (1) Relative advantage is the degree to which innovation is perceived as better than the idea it is supersedes, (2) Compatibility is the degree to which innovation is perceived as being consistent with the existing values, past experiences, and needs of potential adopters, (3) Complexity is the degree to which innovation is perceived as difficult to understand and use, and (4) Trialability is the degree to which an innovation may be experimented with on a limited basis.

The Role of Cooperatives in the Saving and Loan Business for Members : Cooperative is a form of business entity that is recognized in Indonesia and even in the world. Cooperatives have the uniqueness of other forms of business entity in two ways, namely cooperatives aimed at promoting the members economy, and members have a dual identity, namely members as owners of cooperatives and as users of cooperative services [13].

Almost all cooperatives in Indonesia have a savings and loan business, both of which are located as one of the business units in a multipurpose cooperative or as the only cooperative business unit (single purpose). Most savings and loan businesses are still conducted conventionally

Credit cooperatives or savings and loan businesses in cooperatives can function as intermediaries between depositors and borrowing members. Cooperatives collect funds from members and channel it back to other members.

Related to dual identity, in the position of members as owners, members are obliged to contribute to cooperative capital, while as users members must utilize credit business services from cooperatives. With this principle, P2PL mechanism actually occurs in cooperatives, in which as members they are capable of acting as investors, and other members who need funds to act as borrowers.

In fact, many cooperatives have not been able to rely on capital sources from members, so they rely on capital sources as channeling from banks with higher interest costs, consequently the interest expense for members is also high. However, this also faces obstacles, because the ability of cooperatives to access capital 
resources from the banking sector is still very limited. There are still many cooperatives that are not bankable. One reason is that they do not have assets that can be guaranteed. This condition is the rationale for this study to further optimize the sources of cooperative capital from members through a fintech model.

\section{Method of Study}

This study uses quantitative- descriptive methods. Quantitative - descriptive method aims to describe an event or event that is happening now in the form of meaningful numbers (Nana Sudjana, 1997: 53) in [14]. with this method, the study is intended to describe the implementation of fintech in the financial sector business in Indonesia and formulate an appropriate model for the application of fintech in credit cooperatives. A case study was taken at The Fathiyyah Islamic Boarding School Cooperative at Cisayong District, Regency Of Tasikmalaya, West Java Province to support the formulation of the model, based on a descriptive analysis of the feasibility of the innovation. The selection of the Fathiyah Cooperative as a case with consideration of the criteria that the Fathiyah Cooperative as a rural cooperative that represents the community with a relatively low IT literacy, and with a total membership of 20,000 people can represent the socio-economic diversity of the community.

\section{Expected Output}

This study was aimed at answering four research questions as follows: (1) How is the implementation of fintech in the financial sector business in Indonesian society, (2) How is the feasibility of fintech applied to credit cooperatives in Indonesia, (3) What is the right model for fintech implementation in cooperatives credit in Indonesia, (4) What are the policy implications of developing fintech in credit cooperatives in Indonesia

\section{Fact Findings and Result}

\section{Crowdfund and PdPL: Problems and Risks in its Implementation}

Actually loans in the P2PL platform, can be an alternative for traditional financial mediators to develop their business by utilizing IT developments. In this way individuals / families and SMEs can be funded directly by various investors. This condition creates innovation by developing business models on IT platforms, making it easier to bring together users, both in terms of lenders and borrowers. Money transactions are carried out among unrelated individuals [15]

However. As stated in the introduction, the implementation of fintech in Indonesia faces many problems and risks. This is the focus of this study. The problem concerns legality issues, the community's limited understanding of the fintech business so that loans are only seen from the easy and fast side of the process of obtaining funds, but ignores interest rates, final fees and other risks, utilization of customer data by 
irresponsible parties, even to intimidation against defaulted customers, the risk of default, and fraud.

The description of problem and risk in the implementation of PdPL is presented in Table II as follows.

Table Ii: the Problems and Risks of P2pl

\begin{tabular}{|c|c|c|c|c|}
\hline No & $\begin{array}{l}\text { Problem/ } \\
\text { risk }\end{array}$ & Desciption & & \\
\hline 1 & Legal & $\begin{array}{l}\text { In } 2018 \text { and } \\
2019 \text { OJK } \\
\text { had closed } \\
947 \text { fintech, } \\
\text { mainly illegal } \\
\text { P2PL,. }\end{array}$ & & \\
\hline 2 & $\begin{array}{l}\text { Community's } \\
\text { limited } \\
\text { understanding }\end{array}$ & $\begin{array}{l}\text { Many } \\
\text { Indonesians } \\
\text { still don't } \\
\text { understand } \\
\text { about the } \\
\text { fintech } \\
\text { business, } \\
\text { including the } \\
\text { risks, }\end{array}$ & Member Function & Participation \\
\hline 3 & loan & $\begin{array}{l}\text { Capital } \\
\text { owners are } \\
\text { looking for } \\
\text { maximum } \\
\text { profit. those } \\
\text { who need } \\
\text { funds ignore } \\
\text { the } \\
\text { conditions } \\
\text { set by the } \\
\text { capital } \\
\text { owners }\end{array}$ & User Investor & $\begin{array}{l}\text { Members } \\
\text { provide loan } \\
\text { funds / } \\
\text { investments } \\
\text { to other } \\
\text { members in } \\
\text { need }\end{array}$ \\
\hline 4 & Data hacking & $\begin{array}{l}\text { The P2PL } \\
\text { application } \\
\text { system can } \\
\text { access } \\
\text { personal data } \\
\text { that is on the }\end{array}$ & Borrower & $\begin{array}{l}\text { Members } \\
\text { borrow funds } \\
\text { to finance } \\
\text { their } \\
\text { business. }\end{array}$ \\
\hline
\end{tabular}




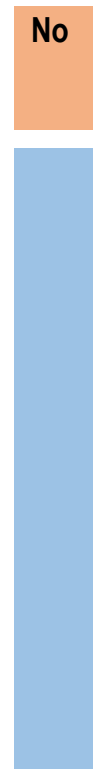

Problem/
risk

\section{Desciption}

\section{borrower's}

cell phone, starting from the contact list, photo gallery, short message history, to family history. Including colleagues and family phone numbers

\section{Intimidation to} consumers

\section{Customers} are often trapped in returning debt. This condition usually continues with intimidation, embarrassing the customer in front of friends and colleagues to sexual harassment

$6 \quad$ Risk of Failure to Pay

The risk of
default is
very high
especially for
illegal P2PL,
with very high
interest and
penalties that

Contributions, of

Control and cooperative

Make members to

decision contribute

capital to the

cooperative,

control and

make

decisions

through

member

meetings. 


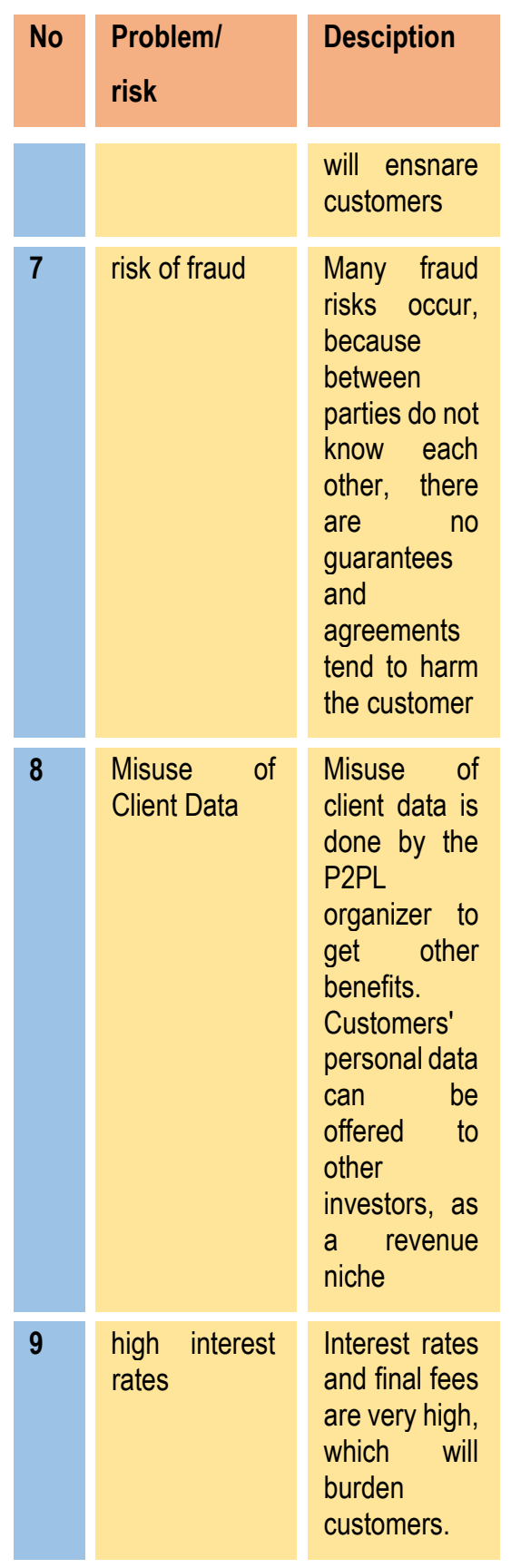

Source: Sugiyanto [16]

P2PL As a Cooperative Business Development Model

Based on the description of the above problems, in this discussion an idea of the 
development model of a cooperative savings and loan business is presented by changing the conventional savings and loan business model to an IT-based savings and loan business using the P2PL platform approach. This model is feasible to be applied in cooperatives, especially for millennial generation which is characterized (one of them) by the mastery of technology known as Technological Savvy. Millennial generation is very closely related to the presence of IT, almost all of its activities by utilizing the sophistication of the technology, ranging from activities to meet everyday needs such as shopping, transportation, traveling, banking affairs, learning processes and also in the search for new knowledge

The P2PL platform can be applied to cooperative savings and loan businesses while maintaining the values and principles of cooperatives, thus the rules of cooperatives do not fade due to the development of IT. The role of the member must be both the user and owner. As users will enjoy the benefits of cooperative services (user-owner, user-control, and user-benefit principles). As the owner means they are the controller and decision maker, so various problems and risks can be reduced.

For members who have excess funds can take advantage of the business model as an investment portfolio with returns that can be negotiated between members of the owners of capital with borrowing members. The decision making process, negotiations and control of members as owners can be carried out at member meetings.

The cooperative business development model using the P2PL platform can be explained as Fig. 1. Description of Fig. 1 about members function as users and owners is shown in the Table III as follows:

Table III: Function of Cooperative Members as Owner and User

\begin{tabular}{|l|l|l|}
\hline $\begin{array}{l}\text { Member } \\
\text { position }\end{array}$ & Function & Participation \\
\hline User & Investor & $\begin{array}{l}\text { Members provide loan funds / investments to } \\
\text { other members in need }\end{array}$ \\
\hline & Borrower & $\begin{array}{l}\text { Members borrow funds to finance their } \\
\text { business. }\end{array}$ \\
\hline Owner & $\begin{array}{l}\text { Capital } \\
\text { Contributions, } \\
\text { Control and } \\
\text { Make decision }\end{array}$ & $\begin{array}{l}\text { Obligations of cooperative members to } \\
\text { contribute capital to the cooperative, control } \\
\text { and make decisions through member } \\
\text { meetings. }\end{array}$ \\
\hline
\end{tabular}


C. Adoption of Fintech Innovation In Credit Cooperatives, Case: The Fathiyyah Islamic Boarding School Cooperative, Cisayong District, Regency of Tasikmalaya, West Java Province

Currently in Indonesia fintech has been adopted by several cooperatives, especially those engaged in the credit business. Cooperatives that implement fintech are large cooperatives, especially in terms of the number of members. One of the cooperatives that has implemented fintech is the Fathiyyah Islamic Boarding School Cooperative at Cisayong District, Tasikmalaya Regency, West Java Province. The fintech application used in this cooperative is named Qini Mobile. This application can be downloaded at Playstore.

This cooperative is interesting to be used as a case in this study, because it is located in a rural area with a total membership of 20,000 people (the number of members is large for the size of cooperatives in Indonesia), with total cooperative assets of Rp $74,683,127,478$ or equivalent to US $\$ 5,000,000$ (this amount is also great for the size of rural cooperatives in Indonesia). Rural areas can be said to represent the community with IT literacy is still limited compared to urban communities, so if fintech can succeed in rural areas it can be expected to be applied in other cooperatives in Indonesia both in rural and urban areas. With a description of the condition of this cooperative, this cooperative is a suitable sample/case in this study.

This cooperative was established in 1983 with Legal Entity No 02 dated March 23, 2019 . There are a number of business activities carried out by this cooperative to serve its members, namely fisheries, agriculture, mini-markets, and saving and loan (credit). In accordance with the focus of this study, the discussion here is focused on credit business only. The credit business managed by the cooperative has developed well, with total loans disbursed to members of Rp 44,887,232,601 (equivalent to US $\$ 3,000,000)$. To support the development of credit business, cooperatives have implemented fintech since 8 February 2018. The application of fintech in this cooperative has had a positive impact on the development of cooperatives, both on the overall financial condition of the cooperative and on the development of the credit business.

In accordance with the context of this study, from the aspect of communication science, the application of fintech as an innovation can be successful in this cooperative because fintech has several advantages as illustrated in Table IV. as follows

Table IV: Inovation Feasibility Analysis for Fintech 


\section{RELATIVE ADVANTAGE: the degree to which an innovation is perceived as better than the idea it supersedes}

There are benefits obtained by cooperatives from the application of fintech applied in the Cooperative starting February 8, 2018

Increase the number of members from 18,000 to 20,000 Increase the number of active members from 10,000 to 15,000

Increase in the number of credit transactions from $\mathrm{Rp}$ $44,887,232,601$ per year to $48,898,333,205$ per year

There is an efficiency of credit processing time from 30 days to 15 days

There is an efficiency in credit costs from Rp 0.09 for each rupiah credit to $\mathrm{Rp} 0.06$ for each rupiah credit

There was a decrease in Non-performance loans from $0.22 \%$ to $0.15 \%$

There was a decrease in operational costs and cooperative overhead cost from Rp 3,205,216,600 / month to Rp $1,325,524,386$ / month

There was an increase in the payment of obligatory member savings from $\mathrm{Rp} 262,258,958$ (65\%) to $\mathrm{Rp}$ $463,583,798$ (85\%)

There was an increase in members' voluntary savings from Rp2,262,258,958 to $\operatorname{Rp~4,463,583,798~}$

Serving as many as 20,000 members faster, more precise, and easier.

The fintech application can support the application of the dual-identity principle of members, namely members as owners and as users of cooperative services. 


\begin{tabular}{|c|c|}
\hline $\begin{array}{l}\text { experiences, and needs } \\
\text { of potential adopters }\end{array}$ & $\begin{array}{l}\text { The fintech application can support the application of } \\
\text { democratic principles in cooperatives by strengthening the } \\
\text { accountability and transparency aspects of cooperative } \\
\text { management }\end{array}$ \\
\hline $\begin{array}{l}\text { COMPLEXITY: } \\
\text { the degree to which an } \\
\text { innovation is perceived } \\
\text { as difficult to } \\
\text { understand and use, }\end{array}$ & $\begin{array}{l}\text { Fintech has less complexity. It is easy to learn by } \\
\text { management and members of cooperatives. } \\
\text { Administrators need } 3 \text { months to learn this application. } \\
\text { Trial application in members is done within } 1 \text { week, and } \\
\text { the members can understand and use it easily }\end{array}$ \\
\hline $\begin{array}{l}\text { TRIALABILITY: } \\
\text { the degree to which an } \\
\text { innovation may be } \\
\text { experimented with on a } \\
\text { limited basis }\end{array}$ & $\begin{array}{l}\text { The fintech application can be tested on one group of } \\
\text { members. Members quickly understand and use the } \\
\text { application in one week. Currently this application has } \\
\text { been used in this cooperative, because members have used } \\
\text { Android software on their mobile phones. }\end{array}$ \\
\hline
\end{tabular}

Source: Primary data on the Fathiyah Cooperative in 2020

Table IV could describe that fintech as a innovation is feasible to apply and develop since it fulfills the four criterions of innovation stated by [12].

\section{Conclusion}

From this study it can be concluded that:

(1) Fintech business practices, especially the P2PL platform in Indonesia, still face many obstacles and risks, ranging from rampant illegal business practices, misuse of customer data, customer intimidation, fraud, default, and high interest rates.

(2) The application of fintech as an innovation has the feasibility of innovation to be applied to cooperatives in Indonesia.

(3) Cooperatives can become the P2PL Platform model, as an alternative business model by changing conventional savings and loan businesses into the P2PL platform. This model can be a solution to various problems in the implementation of fintech in society in Indonesia. With a note that cooperatives values and principles is carried out consistently. Likewise, the consistency in the implementation of the members' functions in participating both as a user and as an owner. As users, members can 
function as lenders/ investors and other members can function as borrowers to finance their businesses.

(4) The policy implication of the findings of this study is that the model of fintech P2PL platform could be developed for credit cooperatives in Indonesia both in rural and urban areas.

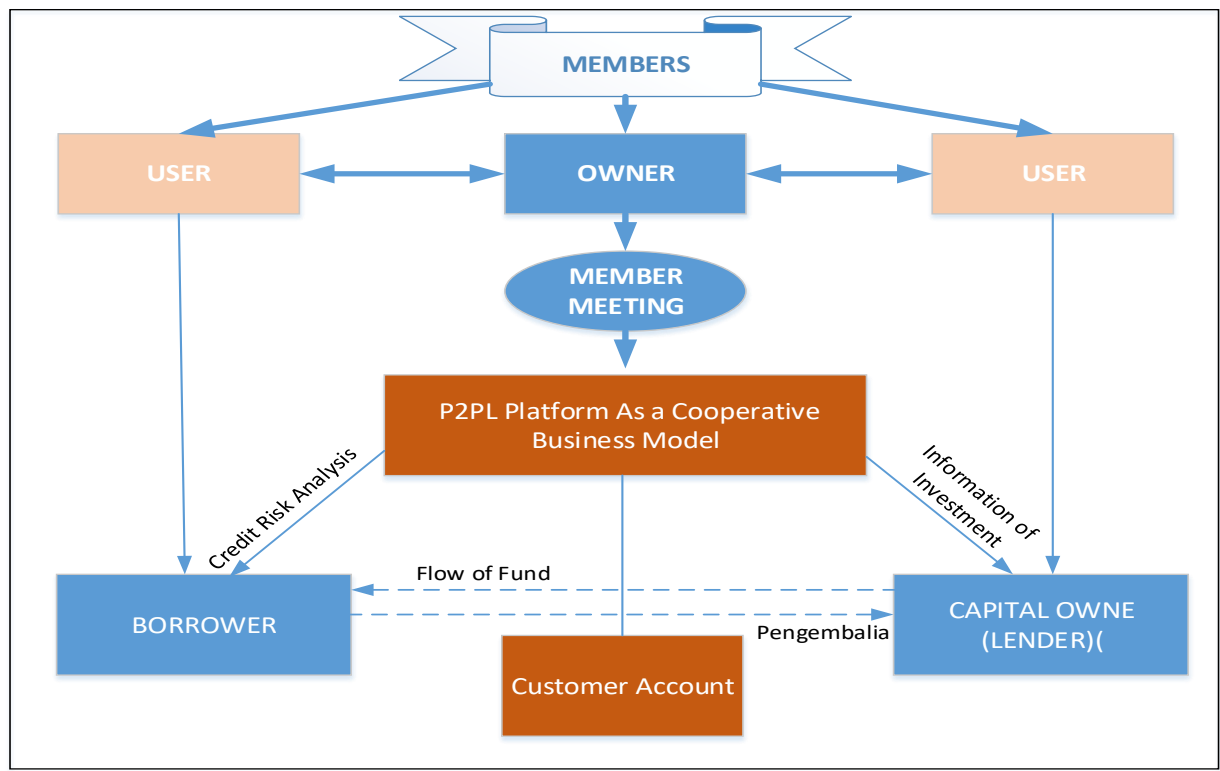

Fig 1.Application of P2PL Model for Savings and Loans (Credit) Cooperatives

\section{References}

[1] P. 77/Pojk.01/2016, "Peraturan Otoritas Jasa Keuangan Nomor 77 /Pojk.01/2016 Tentang Layanan Pinjam Meminjam Uang Berbasis Teknologi Informasi," Ojk.Go.Id, pp. 1-29, 2015.

[2] D. E, "Managerial of Economics of Cooperative," in International Handbook of Cooperative Organization, 1994.

[3] S. and A. A. Rahayu, "The Implementation Of Risk Management And Its Effect On Good Cooperative Governance And Success," vol. 33, no. 3, pp. 243-256, 2018.

[4] Svetlana Saksonova and Irina Kuzmina-Merlino, "Fintech as financial innovation: The possibilities and problems of implementation," Eur. Res. Stud. J., 2017.

[5] D. Anikina, A. V. Gukova, A. A. Golodova, and A. A. Chekalkina, "Methodological aspects of prioritization of financial tools for stimulation of innovative activities," Eur. Res. Stud. J., 2016, doi: 10.35808/ersj/525.

[6] PBI No.18/40/PBI/2016, "PBI 18/40/PBI/2016 Penyelenggaraan Pemrosesan Transaksi Pembayaran," Bank Indones. Off. Web Site, 2016. 
[7] Surat Edaran Bank Indonesia No. 18/22/DKSP, "Penyelenggaraan Layanan Keuangan Digital," 2016.

[8] Bank Indonesia, "Peraturan Bank Indonesia Nomor 18/ 17 /Pbi/2016 Tentang Perubahan Kedua Atas Peraturan Bank Indonesia Nomor 11/12/Pbi/2009 Tentang Uang Elektronik (Electronic Money)," p. h. 1-4, 2016.

[9] Committe on the Global Financial System and Financial Stability Board, FinTech credit: Market structure, business models and financial stability implications. 2017.

[10] M. Hossain and G. O. Oparaocha, "Crowdfunding: Motives, Definitions, Typology and Ethical Challenges," Entrep. Res. J., 2017, doi: 10.1515/erj2015-0045.

A. R. Norris, "Computer-Mediated Communication and Globalization: Considering Social, Academic, and Business Factors," Student Pulse, vol. 4, no. 02, p. 2005, 2012.

[11] E. M. Rogers, "Diffusion Of Innovations Third Edition," J. Contin. Educ. Health Prof., 1983, doi: 10.1002/chp.4750170109.

[12] R. Ariffin, Koperasi Sebagai Perusahaan. Ikopin Press, 2013.

[13] Shinta Margareta, "Hubungan Pelaksanaan Sistem Kearsipan Dengan Efektivitas Pengambilan Keputusan Pimpinan," Repos. UPI, 2013.

[14] K. W. C. Chuang, S. Mo, K. C. Chen, and C. Ye, "The evolving role of peer-to-peer lending: A new financing alternative," J. Int. Acad. Case Stud., 2016.

[15] Sugiyanto, "How to Reduce Financial Technology Risk Through Cooperative Organization?," in Conference on Managing Digital Industry, Technology and Entrepreneurship, 2019. 